\title{
RELATIONSHIP BETWEEN NUTRITIONAL STATUS, HEALTH STATUS, FOOD CONSUMPTION, AND LIFESTYLE TO WORK PRODUCTIVITY OF COCOA FARMER
}

\author{
Wilda Yunieswati ${ }^{1 *}$, Sri Anna Marliyati ${ }^{1}$ and Budi Setiawan ${ }^{1}$ \\ ${ }^{I}$ Departement of Community Nutrition, Faculty of Human Ecology, Bogor Agricultural University, Indonesia
}

\begin{abstract}
Agricultural sector only contributed $14.43 \%$ of total GDP despite labor from this sector is the largest labor force in Indonesia. Cocoa is one of the leading commodities in agricultural sector, sub sector plantation. One of the ways to improve the productivity of cocoa is giving an attention about the good nutrition and good health of the cocoa farmer that have been widely known as a factor to improve work productivity of farmers. This study is cross-sectional study. The objective of this study was to analyze the relationship between nutritional status, health status, food consumption, and lifestyle to work productivity. The subjects were 58 male cocoa farmers in two districts of Polewali Mandar aged 18-65 years old. Most of subjects (39.7\%) have a normal nutritional status and $10.3 \%$ of subjects are central obesity. Then, $46.6 \%$ of subjects have a pre-hypertension. There is no relationship between nutritional statuses to work productivity. Then, there is a relationship between health status (blood pressure) and amount of cocoa picked per day (kilograms) and health status (central obesity) and number of absent days to plantation due to sick
\end{abstract}

Keywords: cocoa farmer, health status, nutritional status, work productivity

\section{Introduction}

The central bereau of statistics notes that labor from agricultural sector is the largest labour force in Indonesia, which reached 37.18 million persons per February 2013. This amount represents $32.61 \%$ of Indonesian total labor force (BPS, 2014). Despite the large population of agricultural labour, the agricultural sector only contributed $14.43 \%$ of total GDP. This condition indicates that work productivity in agriculture sector is low. Cocoa is one of the leading commodities in plantation sub sector. The cocoa development has a potential part in the economy development. Cocoa commodities contribute consistently as a sources of foreign exchange and very important in Indonesia's economic structure (Arsyad, Sinaga, \& Yusuf, 2011). Based on the the economic side, cocoa contributes the third largest foreign exchange after palm oil and rubber (Hasibuan, Nurmalina, \& Wahyudi, 2012). One of cocoa production centers in Indonesia is West Sulawesi. Development of cocoa in West Sulawesi has been done since the 1980s by the local community in here. One of the way to improve the productivity of cocoa is give an attention about the good nutrition and good health of the cocoa farmer.

Health status and nutritional status of workers will influence the work productivity of workers. One of the phenomenon about health status of farmer and people in rural area is non-communicable disease which impacts rural areas as well as the major urban center. Indonesia Basic Health Research (2013) shows an increase in prevalence of non-communicable diseases in West Sulawesi in 2007-2013. Based on various study, there is a significant relationship between nutritional status with work productivity in the traditional rice farmers of Julupamai village. Besides that, there is a strong association between having more health risks and higher presenteeism (Boles, Pelletier, \& Lynch, 2004). The mean percentage of presenteeism (percentage of time impaired at work) rises for each level of cumulative health risks, ranging from $1.3 \%$ average presenteeism for individuals with zero risks to $25.9 \%$ presenteeism for individuals with eight risks. Absenteeism also increases as 
health risks accumulate, with a clear difference between low levels and high levels of risk, but the range is smaller $(0.0 \%$ to $6.3 \%)$ and fluctuates among mid-level of risk. So, employees who have more health risks will experience more absenteeism and presenteeism than employees with fewer risks. Nwaiwu et al. (2016) conducted the study on farmers in Ahiauzu Imo, Nigeria and shows that poor health status would have a negative impact on the productivity of farmers. Various studies above have shown the problem of low productivity with one of the factors is the nutritional status and health status of farmers. Based on these problems, researcher interested to examine the relationship between nutritional status, health status, food consumption, and lifestyle to work productivity of cocoa farmers in Polewali Mandar, West Sulawesi.

\section{Methods}

This study is cross sectional study design and conducted at cocoa plantation in 2 sub-districts (Anreapi District and Mapilli District) located in Polewali Mandar Regency, West Sulwesi Province. The study was conducted in JulyAugust 2017. This study is a part of study entitled Sustainability and Provitability of Cocoa-based Farming Systems in Indonesia collaboration between AIC (Australian-Indonesian Center) with InterCafe LPPM Bogor Agricultural University, Hasanuddin University and Syndey University, Australia. The subjects are 58 male cocoa farmers in 2 sub-districts of Polewali Mandar. The inclusion criteria of the subjects were 1) men aged 18-65 years, 2) cocoa farmers, 3) in a good condition (not sick) when we do the assessment at that time 4) willing and stay in the study site during the study to conduct interviews and anthropometric measurements, body composition and pressure blood directly.

Determination of the minimum number of samples is calculated using the following formula (Sujarweni 2012):

$$
\mathrm{n}=z \frac{a^{2}}{2} \mathrm{p}(1-\mathrm{p}) / \mathrm{d}^{2}
$$

Based on Indonesia Basic Health Research (2013) the prevalence of central obesity among farmers in West Sulawesi is $11.5 \%$. The absolute precision used is $10 \%$ and the confidence level is 95 percent or $\alpha=0.05$ so the minimum number of samples needed in the study after adding $10 \%$ of the anticipated drop-out is 45 people. Minimum sample is 45 people. The sample used in this study was 58 male cocoa farmers who were in accordance with the inclusion and exclusion criteria set by the researchers.

Primary data include subject characteristic, nutritional status (BMI, waist circumference and waist hip ratio), body composition, blood pressure, food consumption (food recall 2x24 hours), eating habits and lifestyle. Data collected through direct interview with subjects.

\section{Anthropometric measurements}

To measure anthropometric variables of weight, height, BMI, waist circumference (WC), hip circumference (HC), waist to hip ratio (WHR) and body compositions, participants were asked to remove their shoes, socks, hat, jewelry, accessories (e.g. watch, keys, cell phone). Body composition was measured using OMRON HBF305 BIA (Bioelectrical Impedance Analysis). The precision of weight, height, and WC was $0.1 \mathrm{~kg}, 0.1 \mathrm{~cm}$ and 0.1 $\mathrm{cm}$, respectively. BMI was computed as follow: weight $(\mathrm{kg}) /($ height $[\mathrm{m}] \times$ height $[\mathrm{m}])(\mathrm{kg} / \mathrm{m} 2)$. Obese was defined as $\mathrm{BMI} \geq 25$. Central obesity was defined as $\mathrm{WC}>90 \mathrm{~cm}$ or $\mathrm{WHR} \geq 0.9$ for men.

\section{Health status measurement}

Health status was measured by case of central obesity and hypertension. Central obesity was defined as Waist circumference $>90 \mathrm{~cm}$ or WHR $\geq 0.9$ for men. Waist and hip circumference are measured using measuring tape (meter). WC is measured in light clothing at the narrowest point immediately below the lowest rib and above the iliac crest; HC was measured at the level of the maximum circumference. WHR was calculated as a waist to hip 
ratio (i.e. $\mathrm{WC}[\mathrm{cm}] / \mathrm{HC}[\mathrm{cm}]$ ). Blood pressure $(\mathrm{BP})$ was measured in a sitting position, and the subject were rested for at least 5 minutes before the measurement. Systolic blood pressure (SBP) and diastolic blood pressure (DBP) were measured using an automated measurement device (Omron, Model HEM-7211, Kyoto, Japan) with a proper cuff size on the left arm. Blood pressure was obtained twice at 1-minute interval, and the average of two readings was used to represent SBP and DBP, respectively. Subject were classified as hypertensive if the SBP $\geq 140 \mathrm{mmHg}$ and DBP $\geq 90 \mathrm{mmHg}$. Subject were classified as pre-hypertensive if the average SBP if the SBP $120-139 \mathrm{mmHg}$ and DBP 80-89 $\mathrm{mmHg}$.

\section{Food Consumption}

Food consumption data includes data intake and type of food using the $2 \times 24$ hours food recall method. The level of adequacy of energy and nutrients (protein, fat and iron) is obtained by comparing the consumption of energy and nutrients with the adequacy of the energy and nutrients of the subject. Calculation of the level of nutritional adequacy is calculated according to the recommended nutritional adequacy (Ministry of Health of Indonesia 2013). Food diversity is assessed using the IDDS (Individual Dietary Diversity Score) method. The way to obtain a food diversity score is to use a 1x24 hour food recall method by paying attention to the weight of food consumed at least 10 grams. The food diversity score category is low (if consuming $\leq 3$ types of food groups every day), moderate (if consuming 4-5 types of food groups every day) and high (if consuming $\geq 6$ types of food groups every day)

\section{Lifestyle}

The lifestyle in this study is seen from the subject's habits of several things. These include smoking in a day (number of stems), daily coffee consumption habits (frequency and amount of coffee consumption), alcohol consumption habits (frequency and amount of alcohol taken), breakfast habits (yes or no), consumption habits of fruit vegetables every day (yes or no) and exercise habits (yes or no, frequency per week). Data obtained by asking directly to farmers using the interview method and filling in the questionnaire.

\section{Work Productivity}

Work productivity in this study was obtained by two ways. The first way was the amount of cocoa picked per day (kilograms) and the second way was the number of absent days to plantation in the last 1 month due to illness/health reason. Data obtained by asking directly to farmers using the interview method.

\section{Statistical Analysis}

The analysis used in this study was spearman-test and pearson-test, based on the normality data and purpose of the study. The, the normality data test used Kolmogorov-smirnov test.

\section{Ethical statement}

The written informed consent was obtained from each participant after explaining the purpose of the study. Ethical approval was approved by the Ethics Committee at Institut Pertanian Bogor (4758/IT3.26.1/KEPMSM/PL/2017). Each participant was also informed that he had the right to terminate the data collection process at any point. Those who did not provide consent to participate were excluded from the study. Data were collected anonymously and was only used for study.

\section{Results}

Table 1 shows that most subjects had a normal nutritional status (39.7\%). Most of the cocoa farmers in the study had normal abdominal circumference $(89.7 \%)$ and $10.3 \%$ of subjects were central obese with abdominal 
circumference greater than 90 centimeters for men. Meanwhile, data from the waist hip ratio measurement, most subjects had a normal WHR of $58.6 \%$ and another $41.4 \%$ had WHR at risk category. Higher the waist circumference and RLPP increases the risk of non-communicable diseases (NCDs) and chronic diseases such as cancer, cardiovascular disease, diabetes, hypertension and others. Then, most subjects had a pre-hypertension. Work productivity in this study defined by 2 ways, the amount of cocoa picked per day (kilograms) and the number of absent days to the plantation due to health reason in the past 1 . Data shows most subjects (62.1\%) picked 1-25 kilograms of cocoa per day and most of subjects $(58,6 \%)$ have zero days for absent day related to health reason in the last 1 month.

Table 1. Characteristics of subjects

\begin{tabular}{|c|c|c|}
\hline Characteristics of subjects & $\mathrm{n}$ & $\%$ \\
\hline \multicolumn{3}{|l|}{ Body mass index } \\
\hline Underweight & 6 & $10.3 \%$ \\
\hline Normal & 23 & $39.7 \%$ \\
\hline Overweight & 15 & $25.9 \%$ \\
\hline \multirow[t]{2}{*}{ Obesity } & 14 & $24.1 \%$ \\
\hline & \multicolumn{2}{|c|}{$22.77 \pm 3.18$} \\
\hline \multicolumn{3}{|l|}{ Waist circumference } \\
\hline Central obesity & 6 & $10.3 \%$ \\
\hline \multirow[t]{2}{*}{ Normal } & 52 & $89.7 \%$ \\
\hline & \multicolumn{2}{|c|}{$78.15 \pm 9.51$} \\
\hline \multicolumn{3}{|l|}{ Waist and hip ratio (WHR) } \\
\hline At risk & 24 & $41.4 \%$ \\
\hline \multirow[t]{2}{*}{ Normal } & 34 & $58.6 \%$ \\
\hline & \multicolumn{2}{|c|}{$0.88 \pm 0.05$} \\
\hline \multicolumn{3}{|l|}{ Blood pressure } \\
\hline Hypertension & 20 & $34.5 \%$ \\
\hline Pre-hypertension & 27 & $46.5 \%$ \\
\hline Normal & 11 & $19.0 \%$ \\
\hline \multicolumn{3}{|c|}{ Number of cocoa picked / day (kg) } \\
\hline 1-25 kilograms & 36 & $62.1 \%$ \\
\hline 26-50 kilograms & 17 & $29.3 \%$ \\
\hline 51-75 kilograms & 1 & $1.7 \%$ \\
\hline 76-100 kilograms & 4 & $6.9 \%$ \\
\hline \multicolumn{3}{|c|}{ Number of days absent due to health reason (days) } \\
\hline 0 days & 34 & $58.6 \%$ \\
\hline 1-3 days & 20 & $34.5 \%$ \\
\hline More than 3 days & 4 & $6.9 \%$ \\
\hline
\end{tabular}

The result of this study shows that there is no relationship between nutritional status, and work productivity of cocoa farmers. The results of this study are in line with the research of Mahardikawati VA (2008) which shows that there is no relationship between nutritional status which is reflected by the body mass index (BMI) with the level of work productivity. This is presumably because the level of work productivity is more influenced by the consumption of nutrients, especially iron. So that IMT is not directly related to work productivity. The relationship between nutritional status and work productivity can be shown in Table 2. 
Table 2: Relationship between nutritional status and work productivity of cocoa farmers

\begin{tabular}{lllll}
\hline & \multicolumn{4}{l}{ Number of cocoa picked / dayNumber of days absent due to health reason } \\
Variable & $\mathrm{r}$ & $\mathrm{p}$ & $\mathrm{r}$ & $\mathrm{P}$ \\
\hline body mass index & 0.087 & 0.516 & -0.230 & 0.083 \\
Body fat percentage-0.067 & 0.618 & $-0,190$ & 0.153 \\
\hline
\end{tabular}

Regarding health status, there is a significant relationship between health status seen by blood pressure and the number of cocoa picked per day (kilograms). The results of this study indicate that someone who has higher blood pressure (suffering from pre-hypertension or hypertension) has lower work productivity when viewed from the number of cocoa picked per day (kilograms). In addition, there is also a significant relationship between health status seen from the incidence of central obesity with the number absent day to the plantation due to health reason. Farmers who suffer central obesity have a higher number of absent day due to health reason compared to farmers who do not suffer from central obesity. Relationship between health status and work productivity can be shown in Table 3.

Table 3: Relationship between health status and work productivity

\begin{tabular}{lllll}
\hline & \multicolumn{3}{c}{ Number of cocoa picked/ day } & \multicolumn{2}{l}{ Number of days absent due to health } \\
Variable & $\mathrm{r}$ & $\mathrm{p}$ & $\mathrm{R}$ & $\mathrm{p}$ \\
\hline Central obesity & 0.114 & 0.392 & 0.275 & $0.037^{\mathrm{a}}$ \\
Hypertension & -0.366 & $0.005^{\mathrm{a}}$ & -0.085 & 0.525 \\
\hline
\end{tabular}

${ }^{\mathrm{a}}$ Correlation test spearman was significantly associated at $\mathrm{p}<0.05$

The result of this study his is consistent with research from Robroek et al. (2010) in 10,624 workers in 49 Dutch companies in 2005-2009 which stated that obese workers had higher sick leave compared to normal weight workers (OR 1.27, 95\% CI 1.11-1.46). Another study from Pronk et al. (2004) on 683 workers showed that work performance was related to the body mass index (BMI) category. Regarding hypertension, the results of this study are in line with the research of Busingye et al. (2014) where it is known that the cause of the decline in work productivity of a person or group is due to an increase in high blood pressure. However, health is not a major factor that can reduce work productivity, work motivation is considered to affect someone's performance.

Table 4 shows the relationship between food consumption and work productivity of cocoa farmers. The food consumption studied included energy intake, protein intake, fat intake, iron intake and food diversity score using the IDDS (Individual Dietary Diversity Score).. Statistical test results related to the relationship between lifestyle and work productivity of cocoa farmers can be seen in table 4.

Table 4: Relationship between food consumption and work productivity

Number of cocoa picked / dayNumber of days absent due to health reason

\begin{tabular}{lllll} 
Work productivity of cocoa farmersr & $\mathrm{p}$ & $\mathrm{r}$ & $\mathrm{p}$ \\
\hline Energy intake & -0.035 & 0.796 & -0.005 & 0.968 \\
Protein intake & -0.144 & 0.281 & 0.127 & 0.342 \\
Fat intake & -0.061 & 0.647 & 0.011 & 0.936 \\
Iron intake & -0.240 & 0.069 & 0.029 & 0.827 \\
Food diversity score (IDDS) & -0.092 & 0.493 & 0.063 & 0.641 \\
\hline
\end{tabular}

Statistical test using the Spearman test showed no association between consumption of food seen from an intake of nutrients to work productivity of cocoa farmers Another study from Mahardikawati VA (2008) on 92 female tea picking subjects in PTPN VIII, Bandung showed that although the levels of energy, protein, vitamin A and 
vitamin $\mathrm{C}$ consumption did not correlate with sample work productivity, high levels of iron consumption were associated with levels high work productivity $(\mathrm{r}=0.248, \mathrm{p}<0.01)$. Then, Statistical tests using the Spearman test showed no relationship between the score of food diversity and the productivity of cocoa farmers. Results from Mahardikawati study (2008) showed that the level of labor productivity is influenced by the level of consumption or intake of specific nutrients especially iron. This study showed that the level of food diversity does not affect the work productivity of cocoa farmers.

Table 5 shows the relationship between lifestyle and work productivity of cocoa farmers. The lifestyle studied was between smoking habits, coffee consumption, alcohol consumption, exercise breakfast and daily consumption of vegetables and fruits. Statistical test results related to the relationship between lifestyle and work productivity of cocoa farmers can be seen in table 5 .

Table 5: Relationship between lifestyle and work productivity

Number of cocoa picked / dayNumber of days absent due to health reason

\begin{tabular}{lllll}
\multicolumn{2}{l}{ Work productivity of cocoa farmersr } & $\mathrm{p}$ & $\mathrm{r}$ & $\mathrm{p}$ \\
\hline Smoking habits & $-0,130$ & 0.330 & 0.182 & 0.171 \\
Coffee consumption habits & 0.077 & 0.566 & 0.125 & 0.658 \\
Alcohol consumption habits & 0.219 & 0.099 & 0.107 & 0.426 \\
Breakfast habits & 0.228 & 0.085 & -0.152 & 0.255 \\
Exercise habits & -0.038 & 0.775 & 0.038 & 0.774 \\
Fruit and vegetable consumption & -0.124 & 0.355 & -0.030 & 0.822 \\
\hline
\end{tabular}

Statistical tests using the Spearman test showed that there was no relationship between the lifestyle of the subject and the work productivity of cocoa farmers. This is presumably because the subject's lifestyle has more influence on health status. Furthermore, health status will affect the level of work productivity, so that lifestyle does not directly affect the work productivity of cocoa farmers. The results of this study are not in line with the research of Robroek et al. (2010) in 10,624 workers in 49 Dutch companies in 2005-2009 showed that smoking (OR 1.45), obesity (OR 1.29) and lack of fruit consumption (OR 1.22) were associated with productivity loss when work

\section{Conclusion}

There is no relationship between nutritional status to work productivity. But, there is a relationship between health status (blood pressure) and amount of cocoa picked per day (kilograms) and health status (central obesity) and number of absent day to plantation due to sick. Recommendations regarding result of this study are improving an education about food diversity, exercise and non-communicable disease (NCDs) and the importance of health care $\&$ nutrition counseling participation in village

\section{Acknowledgements}

We respect and thank to Indonesia Endowment Fund for Education (LPDP) and Australia-Indonesia Center (AIC) for funding and helping us to conduct this study in Polewali Mandar, West Sulawesi

\section{References}

Arsyad, M., Sinaga, B.M., \& Yusuf, S. (2011). Analisis Dampak Kebijakan Pajak Ekspor dan Subsidi Harga Pupuk Terhadap Produksi dan Ekspor Kakao Indonesia Pasca Putaran Uruguay. Jurnal Sosial Ekonomi Pertanian, 8 (1): 63-67. 
Boles, M., Pelletier, B., \& Lynch, W. (2004). The Relationship Between Health Risks and Work Productivity. Journal of Occupational and Environmental Medicine, 46: 737-74.

Busingye, D., Arabshahi, S., Subasinghe, A.K., Evans, R.G., Riddell, M.A., \& Thrift, A.G. (2014). Do the socioeconomic and hypertension gradients in rural populations of low- and middle-income countries differ by geoghrapical region? A systematic review and meta-analysis. International Journal of Epidemiology, 43 (5): 15631577 .

[BPS] Badan Pusat Statistik. (2017). Statistik Ketenagakerjaan Sektor Pertanian tahun 2017. Jakarta (ID): Badan Pusat Statistik

Brumby, S., Chandrasekara, A., \& McCoombe, S. (2012). Cardiovascular risk factors and physiologixal distress in Australian farming communities. Australian Journal of Rural Health, 29 (1), 131-137.

Hasibuan, A.M., Nurmalina, R., \& Wahyudi, A. (2012). Analisis Kinerja dan Daya Saing Perdagangan Biji Kakao dan Produk Kakao Olahan Indonesia di Pasar Internasional. Buletin RISTRI, 3 (1): 57-70

Mahardikawati, V.A. (2008). Aktivitas fisik, konsumsi pangan, status gizi, dan produktivitas kerja wanita pemetik teh di PTPN VIII Bandung, Jawa Barat. (Undergraduate Thesis) Institut Pertanian Bogor.

Nwaiwu, L. U. O., Obasi, P. C., Korie, O.C., Ben Chendo, N.G., Uhuegbulem, I. J., \& Anyanwu, F.C. (2016). Effects of Household Foods on Health Status of Farmers- Implication on Farm Labour Productivity in Ahiazu Mbaise Imo State, Nigeria. presentation at the 91st Annual Conference of the Agricultural Economics Society, Royal Dublin Society in Dublin, Ireland

Pronk, N.P., Martinson, B., Kessler, R.C., Beck, A.L., Simon, G.E., \& Wang, P. (2004). The association between work performance and physical activity, cardiorespiratory fitness and obesity. Journal of Occupational and Environmental Medicine, 46 (5): 19-25.

Robroek, S. J. W., Berg, T. I. J., Plat, J.F., \& Burdorf, A. (2010). The role of obesity and lifestyle behaviours in a productive workforce. Journal of Occupational and Environmental Medicine, 68 (1): 134-139. 